\title{
PENGEMBANGAN INSTRUMEN KECERDASAN EMOSIONAL USIA 5-6 TAHUN
}

\author{
Novianti Retno Utami \\ Fakultas Keguruan dan Ilmu Pendidikan Universitas PGRI Yogyakarta \\ Email: novianti@upy.ac.id
}

\begin{abstract}
Abstrak
Tujuan utama dari penelitian ini adalah untuk mengembangkan instrumen kecerdasan emosional untuk anak usia dini. Instrumen ini terdiri dari tiga dimensi dan faktor pembentuknya seperti dimensi pengetahuan emosi terdiri dari 3 faktor, dimensi ekspresi emosi terdiri dari 3 faktor dan dimensi regulasi emosi terdiri dari 3 dimensi. Populasi dalam penelitian adalah anak usia 5-6 tahun di Kabupaten Magelang, dengan teknik pengambilan sampel multistage random sampling. Jumlah sampel dalam penelitian ini adalah, 267 sampel dari 5 TK. Validitas isi dilakukan oleh pakar, menghasilkan 15 items pada dimensi pengetahuan emosi, 12 item pada dimensi ekspresi emosi dan 13 item pada regulasi emosi. Perhitungan validitas empirik menggunakan analisis faktor, perhitungan reliabilitas perdimensi menggunakan alpha cronbach dan perhitungan reliabilitas multidimensi menggunakan alpha stratified. Pada uji coba ke dua atau skla besar, menghasilkan 40 item dengan tingkat reliabilitas yang tinggi, reliabilitas dimensi pengetahuan emosi 0.875 , dimensi ekspresi emosi 0.714 dan dimensi regulasi emosi 0.807 , reliabilitas multidimensi kecerdasan emosional memperoleh 0.779. Peneliti menyimpulkan bahwa instrumen ini cocok digunakan untuk mengukur kecerdasan emosional anak usia 5-6 tahun.
\end{abstract}

Kata Kunci: Pengembangan Instrumen, Kecerdasan Emosional

\begin{abstract}
The main purpose of this research is to develop a emotional intelligence instrument for early childhood. The instrument has three dimentions and the factor such as emotional knowledge dimention are 3 factors, emotional expression dimention are 3 factors and emotional regulation dimention are 3 factors. The population of the study were earlychildhood in 5-6 years at Magelang Regency with multy stage random sampling. The number of samples required in this study are 267 from 5 kindergarden. Content validity was by profesional judgment found the items of instrument as follow for emotional knowledge dimention are 15 items, emotional expression dimention 12 items and emotional regulation dimention 13 items. Calculation of validity empirik using factor analisys, calculation reliability a dimention using alpha cronbach and for calculation reliability multidimention using alpha stratified. The second try out, results 40 items have a good validity, emotional knowledge reliability 0.875, emotional expression 0.714 and regulation emotion 0.807, reliability multidimention emotional intelligence is 0.799. it is can can be concluded that instrument fits to be used measuring emotional intelligence for 5-6 years old.
\end{abstract}

Keywords: Instrument Development, Emotional Intelligence.

(C) 2019 Novianti Retno Utami Under the license CC BY-SA 4.0

http://jurnal.upmk.ac.id/index.php/pelitapaud 


\section{PENDAHULUAN}

Perkembangan penelitian tentang kecerdasan emosional saat ini terus dikembangkan baik tentang kajian teori maupun alat ukur untuk kecerdasan emosional. Kecendrungan orang untuk terus meneliti dan mengembangkan penelitian tentang kecerdasan emosional dilandasi oleh beberapa penelitian terdahulu yang menyebutkan bahwa kecerdasan emosional merupakan kecerdasan yang sangat fundamental dalam mempengaruhi kesuksesan seseorang selain kecerdasan intelektual.

Keterbatasan kecerdasan intelektual dalam keberhasilan seseorang ditunjukkan oleh riset di Macaussets, Amerika yang menyebutkan membuktikan bahwa proporsi IQ tidak lebih dari $25 \%$ menentukan keberhasilan seseorang. Pengaruh keberhasilan mereka banyak ditentukan oleh kemampuan sederhana yang mereka dapat sewaktu kecil seperti kemampuan menyikapi kegagalan,kemampuan mengendalikan perasaan emosi dan kemampuan hidup berdampingan dengan orang lain.

Meyer \& Salovey (2004:506) menerangkan emotional intelligence as the ability to percieve and express emotions, to understand and use then and to manage emotions so as to foster personal growt. Dengan demikian seseorang yang memiliki kecerdasan emosional dalam dirinya adalah orang yang mampu mengenali setiap emosi yang adal dalam dirinya maupun orang lain baik itu emosi positif maupun emosi negatif. Selain mengenali emosi, seseorang juga harus memiliki kemampuan dalam mengekspresikan emosinya dan meregulasi emosi sehingga orang tersebut dikatakan cerdas secara emosi.

Goleman (1995:149) berpendapat bahwa emotional intelligence is the capacity for recognizing our own feelings and those of others for motivating ourselves and for managing emotions well in ourselves and in our relationships. Pengertian Goleman sejalan dengan apa yang disampaikan oleh Meyer \& Salovey bahwa kecerdasan emosional dalam diri akan nampak ketika seseorang mampu mengenali perasaan diri dan orang lain sehingga mampu memotivasi diri, 
mengelola emosi diri sehingga mampu membangun sebuah hubungan sosial.

Pendapat lain dikemukakan oleh Bar-On (2001:83), berpandangan bahwa kecerdasan emosional adalah serangkaian kemampuan atau sekumpulan kecakapan pribadi, emosi dan sosial yang mempengaruhi kemampuan seseorang untuk berhasil dalam mengatasi tuntutan dan tekanan lingkungan. Patricia Paton (2000:10) lebih menekankan kecerdasan emosional pada kekuatan dibalik singgasana kemampuan intelektual yang merupakan dasar-dasar pembentukan emosi yang mencakup keterampilanketerampilan mengendalikan impuls, optimistis, menyalurkan emosi-emosi yang kuat secara efektif dan menjaga semangat disiplin diri dalam usaha mencapai tujuan. Kecerdasan emosional yang dikembangkan oleh Paton lebih ditujukan sebagai landasan untuk mencapai kesuksesan.

Ma'mun Mubayyidh (2010:7) mendefinisikan kecerdasan emosional sebagai kemampuan untuk menyikapi pengetahuan-pengetahuan emosional dalam bentuk menerima, memahami dan mengelolanya. Sejalan dengan pendapat ahli sebelumnya Susanne dkk (2011:1) mengartikan kecerdasan emosional sebagai kemampuan mental yang berbeda antar individu dalam: ekspresi emosi, pengetahuan emosi dan regulasi emosi.

Berdasarkan uraian di atas dapat ditarik kesimpulan bahwa kecerdasan emosional adalah kemampuan individu dalam beradaptasi serta mampu memecahkan masalah yang berkaitan dengan keadaan emosi diri, orang lain dan hubungan keduanya yang mencangkup a) pengetahuan emosi, b) ekspresi emosi dan c) regulasi emosi.

Mengingat kecerdasan emosi merupakan sentral bagi kehidupan individu, maka penting untuk mendapatkan perhatian lebih dari pendidik dan orang tua. Sehingga perlu pemahaman yang komprehensif mengenai kecerdasan emosional anak baik dari segi mengukur tingkat pemahaman anak terhadap kecerdasan emosional dan pemberian intervensi yang tepat. Oleh karena itu, diperlukan alat tes kecerdasan emosional yang sesuai dengan usia dan tumbuh kembang anak.

Metode tes dalam pengukuran emosi banyak dikembangkan berdasarkan pada teori psikoanalisis. Sebagai praktisi pendidikan anak usia dini kita seharusnya memiliki alat ukur untuk mengukur kecerdasan emosional anak. Guna 
mempermudah pemahaman terhadap emosi, diperlukan suatu pengukuran yang dapat membedakan kondisi kecerdasan emosi individu satu dengan yang lainnya. Terkait dengan kegiatan pengukuran kecerdasan emosional anak, sangat diperlukan suatu instrumen kecerdasan emosional yang teruji baik validitas maupun reliabilitasnya. Untuk itu dalam penelitian ini difokuskan dalam penyusunan dan pengembangan instrumen kecerdasan emosional anak 5-6 tahun yang sesuai dengan tahap perkembangan anak. Penelitian ini akan dikembangkan di Kabupaten Magelang mengingat banyaknya sekolah yang menggunakan tes kecerdasan emosional anak sebelum memasuki sekolah dasar.

\section{METODE PENILITIAN}

Metode penelitian yang digunakan dalam penelitian ini adalah penelitian dan pengembangan adapun produk yang dikembangkan adalah iinstrumen kecerdasan emosional. Pelaksanaan penelitian dilakukan melalui uji pakar dan uji coba instrumen sebanyak 2 kali. Dimensi kecerdasan emosional yang diukur yaitu 1) pengetahuan emosi (emotional knowledge), 2) ekspresi emosi (emotional expression) dan 3) regulasi emosi (emotional regulation).

Populasi penelitian ini adalah seluruh anak TK B di Kabupaten Magelang dan sampel diambil dengan teknik multi stage random sampling. Jumlah sampel yang digunakan dalam uji coba 1 sebanyak 157 anak dan untuk uji coba 2 sebanyak 267 anak. Jumlah sekolah yang digunakan untuk uji coba instrumen sebanyak lima sekolah TK B di Kabupaten Magelang.

Kisi-kisi instrumen dikembangkan berdasarkan teori kemudian diturunkan ke dalam definisi konseptual dan definisi operasional yang menjelaskan bahwa kecerdasan emosional adalah skor kemampuan individu dalam beradaptasi serta mampu memecahkan masalah yang berkaitan dengan keadaan emosi diri, orang lain dan hubungan kedua-duanya yang diukur melalui a) pengetahuan emosi, b) ekspresi emosi dan c) regulasi emosi pada anak usia 5-6 tahun.

Penelitian pengembangan instrumen kecerdasan emosional ini menggunakan instrumen berbentuk rating scale. Penskalaan yang digunakan adalah 
skala likert dengan skala 1 sampai 3. Hal tersebut didasarkan bahawa tes kecerdasan emosional adalah tes non kognitif untuk mengukur apa yang dikerjakan atau dirasakan oleh orang.

Analisis data yang digunakan yaitu analisis data kualitatif dan kuantitaif. sebelum instrumen diuji cobakan ke lapangan, instrumen yang sudah terbentuk terlebih dahulu dinilai oleh pakar emosi anak usia dini, pakar bahasa dan pakar anak usia dini.

Hasil penilaian pakar kemudian dihitung validitas dan reliabilitas menggunakan formula Aiken's dan reliabilitas alpha Cronbach. Sedangkan, hasil uji coba kemudian dihitung validitas dan reliabilitasnya. Perhitungan validitas menggunakan analisis faktor sedangkan perhitungan reliabilitas peneliti menggunakan alpha cronbach untuk reliabilitas perdimensi dan alpha stratified untuk reliabilitas multi dimensi.

Gambar 1. Langkah-Langkah Pengembangan Instrumen Kecerdasan Emosi

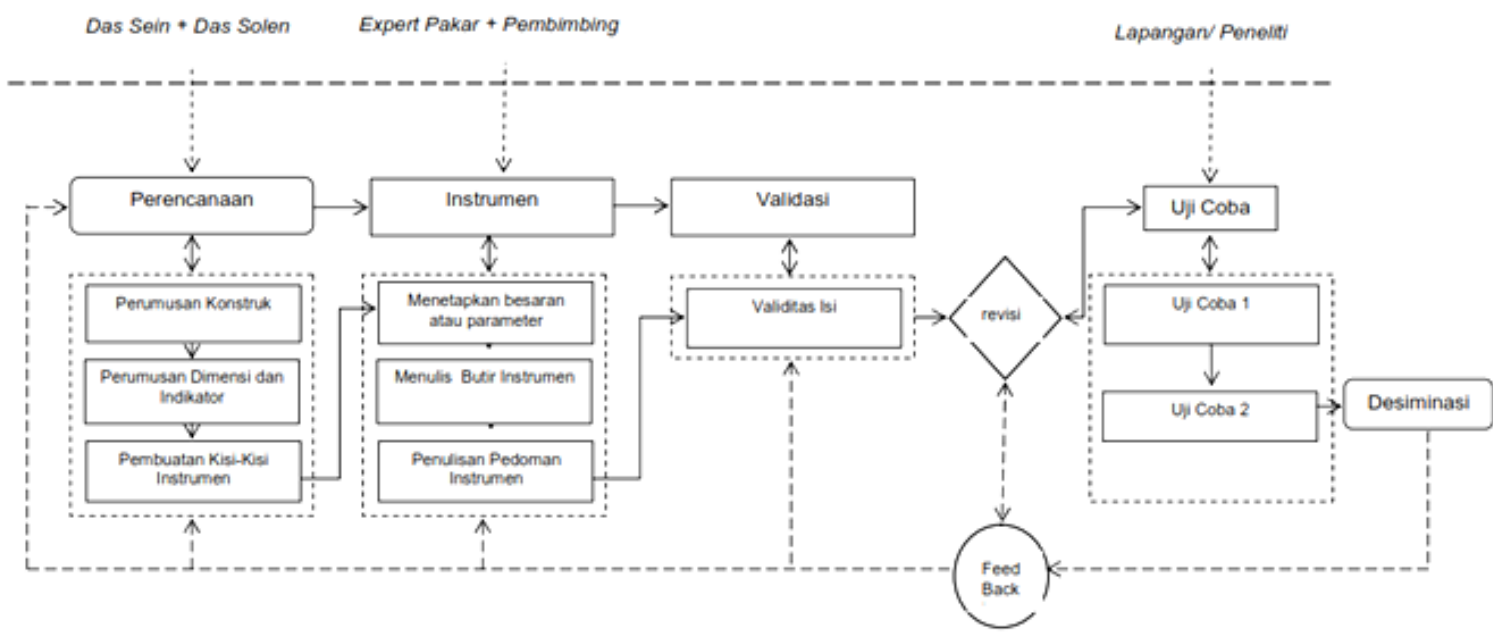




\section{HASIL DAN PEMBAHASAN}

Hasil penelitian menunjukkan bahwa instrumen kecerdasan emosional memiliki validitas dan reliabilitas yang cukup baik. Hal tersebut nampak pada hasil uji pakar dan uji coba 1 dan uji coba 2.

\section{Uji Pakar}

Hasil penilaian pakar secara kualitatif menunjukkan bahwa beberapa item mengalami revisi baik dari segi tata bahasa, teknik penilaian yang digunakan maupun kesesuaian item dengan perkembangan anak usia dini. Perhitungan secara kuantitatif sudah menunjukkan tingkat validitas dan reliabilitas yang memadai.

Perhitungan validitas pakar kesesuaian dimensi dengan variabel dapat di lihat pada tabel berikut ini.
Tabel 1. Perhitungan $\sum \mathrm{s}$ dan Validitas Aiken's Kesesuaian Dimensi dengan Variabel

\begin{tabular}{cccc}
\hline No & $\mathbf{1}$ & $\mathbf{2}$ & $\mathbf{3}$ \\
\hline$\sum \mathbf{s}$ & 29 & 28 & 28 \\
$\mathbf{V}$ & 0,9062 & 0,8750 & 0,8750 \\
\hline
\end{tabular}

Nilai validitas lebih besar dari

0,500 maka dapat dikatakan memiliki nilai validitas yang tinggi. digunakan untuk penelitian tahap selanjutnya. Hasil perhitungan reliabilitas antar penilai diperoleh koefisien reliabilitas sebesar $r_{x x^{1}}=0,945 . \mathrm{r}$ hitung lebih besar dari batas atau standar penerimaan koefisien reliabilitas yang ditetapkan yaitu $r_{x x^{1}} \geq$ 0,70 .

Perhitungan validitas dan reliabilitas kesesuain indikator dengan dimensi menunjukkan bahwa seluruh indikator memiliki nilai validitas yang memadai seperti yang ditunjukkan pada tabel berikut ini:

Tabel 2. Perhitungan $\sum$ s dan Validitas Aiken's kesesuaian indikator dengan dimensi

\begin{tabular}{cccccccccc}
\hline No & 1 & 2 & 3 & 4 & 5 & 6 & 7 & 8 & 9 \\
\hline$\sum \mathrm{s}$ & 30 & 29 & 31 & 28 & 29 & 30 & 27 & 28 & 26 \\
$\mathrm{~V}$ & 0,9375 & 0,9062 & 0,9687 & 0,8750 & 0,9062 & 0,9375 & 0,8437 & 0,8750 & 0,8125 \\
\hline
\end{tabular}

Hasil perhitungan reliabilitas antar penilai diperoleh koefisien reliabilitas sebesar $r_{x x^{1}}=0,945 . r$ hitung lebih besar dari batas atau standar penerimaan 
koefisien reliabilitas yang ditetapkan yaitu $\quad r_{x x^{1}} \geq 0,70$. Hal tersebut menunjukkan adanya kesepakatan antara pakar terhadap hasil penilaian kesesuaian variabel dengan dimensi.

Selain menilai kesesuaian variabel dengan dimensi, dimensi dengan indikator, pakar juga menilai kesesuaian butir, prosedur asesmen dan kriteria skor penilaian. Hasil uji validitas dan reliabilitas kesesuaian butir, prosedur asesmen dan kriteria skor penilaian dapat dilihat pada tabel berikut ini.

Tabel 3. Perhitungan Nilai V Kesesuaian Butir, Prosedur Asesmen dan Kriteria Skor Penilaian

\begin{tabular}{cccccccc}
\hline No & $\mathbf{V}$ & No & $\mathbf{V}$ & No & $\mathbf{V}$ & No & $\mathbf{V}$ \\
\hline 1 & 0,969 & 11 & 0,844 & 21 & 0,688 & 31 & 0,750 \\
2 & 0,969 & 12 & 0,813 & 22 & 0,656 & 32 & 0,719 \\
3 & 0,969 & 13 & 0,750 & 23 & 0,625 & 33 & 0,625 \\
4 & 0,969 & 14 & 0,813 & 24 & 0,656 & 34 & 0,719 \\
5 & 0,969 & 15 & 0,781 & 25 & 0,656 & 35 & 0,844 \\
6 & 0,656 & 16 & 0,844 & 26 & 0,625 & 36 & 0,656 \\
7 & 0,625 & 17 & 0,875 & 27 & 0,625 & 37 & 0,656 \\
8 & 0,625 & 18 & 0,750 & 28 & 0,781 & 38 & 0,688 \\
9 & 0,625 & 19 & 0,813 & 29 & 0,781 & 39 & 0,656 \\
10 & 0,625 & 20 & 0,813 & 30 & 0,781 & 40 & 0,656 \\
\hline
\end{tabular}

Nilai koefisien Aiken's V berkisar antara $0-1$. Koefisien sebesar 0,969 (item 1), 0,969 (item 2), 0,969 (item 3), 0,969(item4) dan 0,969(item 5)...0.656 (item 40) ini sudah dapat dianggap memiliki validitas isi yang memadai ataudapat dikatakan memiliki validitas yang tinggi.

Hasil perhitungan reliabilitas antar penilai diperoleh koefisien reliabilitas antar penilai sebesar 0,766. $r$ hitung lebih besar dari batas atau standar penerimaan koefisien reliabilitas yang ditetapkan yaitu $r_{r x^{1}} \geq 0,70$.

\section{Uji Coba 1}

Setelah melalui uji empririk dari pakar, instrumen kemudian di revisi sesuai dengan saran pakar. Hasil revisi kemudian digunakan untuk melakukan uji coba tahap 1 pada 157 anak. Hasil uji coba tahap 1 kemudian dihitung validitas faktorial dan reliabilitasnya. Hasil 
perhitungan validitas faktorial uji coba 1 dapat dilihat pada tabel berikut.

Tabel 4. Rekapitulasi Hasil Validitas Konstruk dari Analisis Faktor dan Tahap Uji Empiris

\begin{tabular}{|c|c|c|c|c|c|c|c|c|c|}
\hline \multirow{3}{*}{ Tahap } & \multirow{3}{*}{ Dimensi } & \multicolumn{4}{|c|}{ Uji Kelayakan Sampel } & \multicolumn{4}{|c|}{ Ekstraksi dan Rotasi Faktor } \\
\hline & & \multirow{2}{*}{ KMO } & \multicolumn{3}{|c|}{ Barlett's Test of Sphericity } & \multirow{2}{*}{ Total } & \multicolumn{3}{|c|}{ Anggota } \\
\hline & & & Chi Square & df & $\operatorname{sig}$ & & Total & Min & Max \\
\hline \multirow{3}{*}{$\begin{array}{l}\text { Uji Coba } \\
1\end{array}$} & $\begin{array}{l}\text { Pengetahuan } \\
\text { Emosi }\end{array}$ & 0,815 & 903,639 & 105 & 0,000 & 4 & 15 & 0,570 & 0,857 \\
\hline & Ekspresi Emosi & 0,681 & 379,971 & 66 & 0,000 & 4 & 12 & 0,432 & 0,810 \\
\hline & Regulasi Emosi & 0,690 & 732,678 & 78 & 0,000 & 3 & 13 & 0,441 & 0,890 \\
\hline
\end{tabular}

Muatan faktor pada dimensi uji coba emosi membentuk 3 faktor.

1 menunjukkan bahwa tidak ada butir yang

melewati factor loading lebih kecil dari 0,30 $(<0,30)$ dan lebih besar dari $-0,30(>-0,30)$ sehingga dapat dikatakan semua butir pada uji coba 1 dinyatakan valid. Faktor yang terbentuk di uji 1 sebanyak 11 muatan faktor. Dimensi pengetahuan emosi membentuk 4 faktor, dimensi ekspresi emosi
Uji reliabilitas pada uji coba 1 untuk koefisien reliabilitas perdimensi maupun multidimensi diperoleh indeks koefisien reliabilitas lebih besar dari kriteria yang telah ditentukan yaitu 0,70. Rangkuman hasil analisis reliabilitas untuk tahap uji coba disajikan pada tabel berikut ini.

Tabel 5. Rangkuman Hasil Uji Reliabilitas pada Tahap Ujicoba 1 dan Ujicoba 2

\begin{tabular}{clccc}
\hline Tahap & \multicolumn{1}{c}{ Dimensi } & $\begin{array}{c}\text { Perdimensi } \\
(\text { Alpha } \\
\text { Cronbach) }\end{array}$ & $\begin{array}{c}\text { Multidimensi } \\
\text { (Alpha } \\
\text { Stratified) }\end{array}$ & $\begin{array}{c}\text { Jumlah } \\
\text { Butir }\end{array}$ \\
\hline Ujicoba 1 & Pengetahuan Emosi & 0,860 & 0,772 & 15 \\
& Ekspresi Emosi & 0,666 & & 12 \\
& Regulasi Emosi & 0,797 & & 13 \\
\hline
\end{tabular}




\section{Uji Coba 2}

Uji coba 2 dilakukan setelah tahap perhitungan hasil uji coba 1. Sampel yang digunakan pada tahap uji coba 2 yaitu sebesar 256 anak dan dilakukan di 5 TK di Kabupaten Magelang. Hasil uji coba 2 selanjutnya akan dihitung validitas dengan validitas faktorial dan perhitungan reliabilitas menggunakan reliabilitas alpha cronbach untuk perhitungan perdimensi dan perhitungan reliabilitas antar dimensi menggunakan alpha stratified. Perhitungan validitas factorial dapat dilihat pada tabel berikut ini.

Tabel 6. Rekapitulasi Hasil Validitas Konstruk dari Analisis Faktor dan Tahap Uji Empiris

\begin{tabular}{llccccccccc}
\hline \multirow{2}{*}{ Tahap } & \multicolumn{1}{c}{ Dimensi } & \multicolumn{3}{c}{ Uji Kelayakan Sampel } & \multicolumn{4}{c}{ Ekstraksi dan Rotasi Faktor } \\
& & KMO & \multicolumn{2}{c}{ Barlett's Test of Sphericity } & Total & Total & Minggota & Max \\
\hline \multirow{3}{*}{$\begin{array}{l}\text { Uji Coba } \\
2\end{array}$} & Pengetahuan & Emosi & 0,862 & 1637,584 & 105 & 0,000 & 3 & 15 & 0,660 & 0,822 \\
& Ekspresi Emosi & 0,736 & 807,425 & 66 & 0,000 & 3 & 12 & 0,541 & 0,823 \\
& Regulasi Emosi & 0,739 & 1473,390 & 78 & 0,000 & 4 & 13 & 0,677 & 0,930 \\
\hline
\end{tabular}

Muatan faktor pada dimensi uji dinyatakan valid. Faktor yang terbentuk coba 1 menunjukkan bahwa tidak ada di uji 1 sebanyak 10 muatan faktor. butir yang melewati factor loading lebih Dimensi pengetahuan emosi membentuk kecil dari $0,30(<0,30)$ dan lebih besar 3 faktor, dimensi ekspresi emosi dari $-0,30 \quad(>-0,30)$ sehingga dapat membentuk 3 faktor dan dimensi regulasi dikatakan semua butir pada uji coba 2 emosi membentuk 4 faktor.

Tabel 7. Rangkuman Hasil Uji Reliabilitas pada Tahap Ujicoba 1 dan Ujicoba 2

\begin{tabular}{clccc}
\hline Tahap & \multicolumn{1}{c}{ Dimensi } & $\begin{array}{c}\text { Perdimensi } \\
(\text { Alpha } \\
\text { Cronbach })\end{array}$ & $\begin{array}{c}\text { Multidimensi } \\
\text { (Alpha } \\
\text { Stratified })\end{array}$ & $\begin{array}{c}\text { Jumlah } \\
\text { Butir }\end{array}$ \\
\hline Ujicoba 2 & Pengetahuan Emosi & 0,875 & 0,799 & 15 \\
& Ekspresi Emosi & 0,714 & & 12 \\
& Regulasi Emosi & 0,807 & & 13 \\
\hline
\end{tabular}


Uji reliabilitas pada uji coba 1 untuk koefisien reliabilitas perdimensi maupun multidimensi diperoleh indeks koefisien reliabilitas lebih besar dari kriteria yang telah ditentukan yaitu 0,70. Rangkuman hasil analisis reliabilitas untuk tahap uji coba dapat dilihat pada tabel 7

Dengan demikian, hasil analisis aktor dengan metode Principal Component Analysis (PCA) menunjukkan bahwa instrumen kecerdasan emosional pada anak usia 5-6 tahun yang dikembangkan telah memenuhi kriteria validitas dan reliabilitas yang baik.

Selain terpenuhinya validitas konstruk dan reliabilitas terhadap instrumen kecerdasan emosional yang dikembangkan, pada uji empirik semua instrumen yang diuji cobakan kepada 267 siswa TK B, diisi oleh penilai sesuai dengan petunjuk, cara pengisian dan contoh penilaian yang tercantum dalam pedoman penilaian. Hal ini mencerminkan bahwa dari segi keterbacaan dan kemudahan memahami petunjuk dan isi instrumen cukup memadai.

\section{Pembahasan}

Berdasarkan hasil uji pakar dan uji coba empirik menghasilkan sebuah instrumen kecerdasan emosinal yang terdiri 40 item yang sudah tervalidasi. Instrumen yang dihasilkan

Instrumen kecerdasan emosional anak usia 5-6 tahun yang peneliti rancang melibatkan beberapa teknik penilaian. Penggabungan beberapa teknik penilaian dimaksudkan untuk memperoleh informasi kecerdasan emosional anak sebanyak mungkin baik dari sisi anak sendiri, orang dewasa dan teman sebaya. Hal tersebut juga dijelaskan oleh Laurel dan Sarah sebagai berikut

"With regard to other raters, most respondents suggested adults who knew the children and possibly peers were the appropriate sources of information; 'adults who are in regular contact with the child, i.e. health visitors, teachers and teaching assistants' (PSHE coordinator) or alternatively, 'the individuals who actually rate the child are teachers and parents who are with children on a daily basis' (US researcher)".

$$
\text { Laurel dan Sarah (2002:24) }
$$
menjelaskan bahwa penilaian yang paling baik yaitu penilaian yang melibatkan 
orang dewasa atau teman sebaya. Pertimbangan melibatkan orang dewasa (guru atau orang tua) dan teman sebaya dikarenakan mereka adalah orang yang sering berhubungan langsung dengan anak sehingga mengetahui kebiasaan anak sehari-hari.

Pengambilan nilai kecerdasan emosional dilakukan melalui beberapa teknik seperti, observasi, tanya jawab, dan melalui gambar. Penilaian observasi dilakukan dengan melihat perilaku anak sehari-hari baik di rumah maupun di sekolah. Penilaian tanya jawab dilakukan dengan prosedur yang ada di panduan instrumen. Penilaian juga dilakukan dengan menggunakan media gambar ekspresi yang dipraktikan oleh penilai.

Konstrak kecerdasan emosional lebih ditekankan pada kecerdasan emosional anak usia 5-6 tahun. Instrumen kecerdasan emosional anak usia 5-6 tahun ini terdiri dari 3 dimensi yaitu dimensi pengetahuan emosi, dimensi ekspresi emosi dan dimensi regulasi emosi. Dimensi yang terbentuk berdasarkan konstruk 6 teori para ahli kecerdasan emosi. Dimensi pengetahuan emosi ditujukan untuk mengukur pengetahuan anak tentang kecerdasan emosional terutama pada emosi primer (senang, sedih, marah, takut dan terkejut). Pengetahuan emosi terdiri dari kemampuan anak dalam memahami emosi dalam diri, emosi orang lain dan penyebab dari emosi. Sebelum mengenali ekspresi emosi seseorang, seorang anak harus memiliki pengetahuan tentang emosi yang memadai. LaFreniere (2000:177) mengungkapkan bahwa:

During the toddler and preschool years, children become increasing sophisticated in their abilities to identify emotional expressions. A number studies have investigated the young child's ability to recognize and label spontaneous and posed facial expressions of different basic emotions, often using still photographs as experimental stimuli.

LaFreniere menjelaskan, anak balita dan preschool meningkatkan keahliannya dalam mengidentifikasi ekspresi emosi. Beberapa studi menyelidiki kemampuan awal anak dalam mengenali dan menandai ekspresi wajah yang membedakan emosi umum. Jadi, dapat dikatakan bahwa anak usia dini sudah mampu untuk mengenali emosi orang lain melalui raut wajah yang ditampilkan oleh orang. Oleh karena itu, 
teori tersebut sudah sesuai dengan konstruk dimensi pengetahuan emosi dan dimensi ekspresi emosi.

Kemampuan anak dalam meregulasi emosi umumnya disamakan dengan proses seorang anak dalam memonitor dan mengontrol keadaan emosinya dan mengekspresikan keadaan tersebut untuk beradaptasi pada situasi sosial yang berbeda. Thompson berpendapat bahwa regulasi emosi terdiri dari proses instrinsik dan ekstrinsik untuk memonitor, mengevaluasi dan memodifikasi reaksi emosi. Anak akan memiliki kemampuan regulasi yang baik ketika mereka mampu memahami emosi yang terjadi pada dirinya, sehingga anak mampu mengekspresikan emosi dalam diri dengan baik.

$$
\text { Penilai dalam instrumen }
$$

kecerdasan emosional bisa dilakukan oleh guru, orang tua atau orang yang membutuhkan lainnya. Instrumen ini diharapkan mampu digunakan oleh semua kalangan yang membutuhkannya. Waktu yang dibutuhkan dalam pelaksanaan tes tergantung pada tingkat kecerdasan anak, semakin anak cerdas maka tes akan berlangsung cepat sebaliknya dengan anak yang kurang cerdas, tes akan berlangsung lama. Rata-rata waktu yang dibutuhkan untuk menyelesaikan tes antara 15-20 menit per anak.

Pedoman penskoran pada setiap butir mengacu pada item instrumen yang hendak dinilai. Penilaian dilakukan dengan memberikan tanda $(\sqrt{ })$ pada kolom penilaian. Penilaian terdiri dari 3 skor yaitu 1 untuk anak yang salah dalam menjawab atau memiliki sikap yang kurang baik, skor 2 anak mampu menjawab walau dengan bantuan dan memiliki sikap yang cukup baik dan 3 merupakan skor untuk anak yang memiliki jawaban atau sikap yang baik.

Penafsiran terhadap hasil penilaian kecerdasan emosional pada anak usia 5-6 tahun dengan instrumen yang dikembangkan ini, dibuat rentang hasil penilaian kecerdasan emosional seperti disajikan pada tabel berikut ini. 
Tabel 8. Rentang Nilai Kecerdasan Emosional Anak Usia 5-6 Tahun

\begin{tabular}{ll}
\hline \multicolumn{1}{c}{ Skor dan Rentang Penilaian } & \multicolumn{1}{c}{ Penafsiran Hasil Penilaian } \\
\hline $40 \leq X<67$ & Anak memiliki EQ rendah \\
$67 \leq X<93$ & Anak memiliki EQ sedang \\
$93 \leq X \leq 120$ & Anak memiliki EQ tinggi \\
\hline
\end{tabular}




\section{SIMPULAN}

Berdasarkan hasil analisis data dan pembahasan maka dapat dikemukakan beberapa kesimpulan bahwa instrumen kecerdasan emosional yang terbentuk memiliki 3 dimensi yaitu dimensi kecerdasan emosional, dimensi ekspresi emosi dan dimensi regulasi emosi.

Hasil pengujian validitas konstruk terhadap instrumen kecerdasan emosional anak usia 5-6 tahun yang dikembangakn menunjukkan bahwa pada semua tahap pengujian, baik tahap uji coba teoritik maupun tahap uji coba empirik 1 dan 2 telah memenuhi kriteria validitas yang cukup berarti. Ini tampak dari hasil analisis uji coba 1 dengan analisis faktor, semua indikator butir pada masing-masing dimensi memiliki muatan faktor atau factor loading > 0,30. Demikian juga dengan hasil analisis tahap uji coba 2 dengan analisis faktor, menunjukkan bahwa semua indikator butir pada masing-masing dimensi memiliki muatan faktor $>0,30$. Dengan demikian 3 dimensi dengan 9 indikator butir telah memenuhi kriteria instrumen valid.
Hasil uji reliabilitas menunjukkan bahwa instrumen yang dikembangkan telah memenuhi kriteria instrumen yang reliabel, yang ditunjukkan dengan capaian koefisien reliabilitas pada setiap pengujian, baik teoritik maupun empirik menggunakan koefisien Alpha Cronbach dan Alpha Stratified. Konstruk reliabilitas telah memenuhi standar yang ditetapkan yakni $r_{x x^{1}} \geq 0,70$

Penskoran terhadap instrumen kecerdasan emosional anak usia 5-6 tahun yang dikembangkan dilakukan 2 tahap.

Penskoran terhadap butir. Skor pada setiap butir instrumen ditentukan berdasarkan kecerdasan emosional yang terpenuhi atau tampak pada saat dilaksanakannya penilaian. Nilai tertinggi untuk masing-masing butir instrumen sama dengan 3 dan nilai terendah sama dengan 1 .

Penskroran berdasarkan keseluruhan butir ditafsir menggunakan model kategorisasi jenjang. Untuk menentukan kecerdasan emosional yang dinilai berada pada kategori memiliki kecerdasan rendah, sedang atau tinggi digunakan patokan rata-rata teoritis $(\mu)$ 
dan simpangan baku teoritis $(\sigma)$ dengan ketentuan:

$X<(\mu-1 \sigma)=$ Anak memiliki EQ tinggi

$(\mu-1 \sigma) \leq X<(\mu+1 \sigma)=$ Anak memiliki EQ sedang

$\mathrm{X} \geq(\mu+1 \sigma)=$ Anak memiiki EQ rendah

Hasil penilaian kemudian dijadikan dasar untuk memetakan anak yang memiliki kecerdasan emosional yang tinggi, sedang atau rendah. Sehingga, guru maupun orang tua mampu memberikan stimulus yang tepat untuk meningkatkan kecerdasan emosional anak.

\section{DAFTAR PUSTAKA}

Azwar, Saifuddin. (2004). Dasar-Dasar Psikometri (Yogyakarta: Pustaka Pelajar).

Bar-On, Reuven. The 5 Meta Factors and Sub -Factors of the Bar-On Model.2009., (www.baronreuven.org), diakses 26 September 2015, pukul 13.15 WIB

(2001). Emotional Intelligence and Self Actualization (in Joseph Ciarrochi, Joseph P.Forgas and John D.Mayer (Eds).Emotional Intelligence in Everyday Life a Scientific Inquiry (Philadelphia: Psychology Press).

Denham, (2011). Susanne dkk.Emotional Intelligence in the first Five Years of Life.(USA: George Mason University.
Edmund, Laurel \& Stewart Brown Sarah. (2002). Assessing Emotional dan Social Competences in Primary School and Early Years Setting, A Review of Approaches, Issues and Instruments.University of Oxford: Institute Service Risearch Unit.

Golemen,Daniel. (1995). Emotional Intelligence Why It Can Matter More Than IQ (New York: Bantam Books).

J.LaFreniere, Peter. (2000). Emotional Development: a Biosocial Perspective.(USA:Wadsworth)

Mubayyidh, Ma'mun.Kecerdasan dan Kesehatan Emosional Anak, terjemahan M. Muchson Anasy. (2010). Jakarta: Pustaka Al Kautsar.

Patton, Patricia. (2000). EQ Landasan untuk Meraih Sukses Pribadi dan Karir, terjemahan Hermes (Jakarta: Mitra Media. 